\title{
Gap analyses of priority wild relatives of food crop in current ex situ and in situ conservation in Indonesia
}

\author{
Wiguna Rahman ${ }^{1,2}$ (D) Joana Magos Brehm ${ }^{1} \cdot$ Nigel Maxted $^{1} \cdot$ Jade Phillips $^{1}$. \\ Aremi R. Contreras-Toledo ${ }^{3} \cdot$ Mariam Faraji $^{1} \cdot$ Mauricio Parra Quijano $^{4}$
}

Received: 9 May 2020 / Revised: 31 May 2021 / Accepted: 8 June 2021 /

Published online: 6 July 2021

(c) The Author(s) 2021

\begin{abstract}
Conservation programmes are always limited by available resources. Careful planning is therefore required to increase the efficiency of conservation and gap analysis can be used for this purpose. This method was used to assess the representativeness of current ex situ and in situ conservation actions of 234 priority crop wild relatives (CWR) in Indonesia. This analysis also included species distribution modelling, the creation of an ecogeographical land characterization map, and a complementarity analysis to identify priorities area for in situ conservation and for further collecting of ex situ conservation programmes. The results show that both current ex situ and in situ conservation actions are insufficient. Sixtysix percent of priority CWRs have no recorded ex situ collections. Eighty CWRs with ex situ collections are still under-represented in the national genebanks and 65 CWRs have no presence records within the existing protected area network although 60 are predicted to exist in several protected areas according to their potential distribution models. The complementarity analysis shows that a minimum of 61 complementary grid areas (complementary based on grid cells) are required to conserve all priority taxa and 40 complementary protected areas (complementary based on existing protected areas) are required to conserve those with known populations within the existing in situ protected area network. The top ten of complementary protected areas are proposed as the initial areas for the development of CWR genetic reserves network in Indonesia. It is recommended to enhanced coordination between ex situ and in situ conservation stakeholders for sustaining the long term conservation of CWR in Indonesia. Implementation of the research recommendations will provide for the first time an effective conservation planning of Indonesia's CWR diversity and will significantly enhance the country's food and nutritional security.
\end{abstract}

Keywords Conservation - Complementarity analysis - Crop wild relatives · Ecogeographic land characterization $\cdot$ Ex situ $\cdot$ In situ $\cdot$ Gap analysis $\cdot$ Indonesia

Communicated by Daniel Sanchez Mata.

This article belongs tothe Topical Collection: Ex-situ conservation.

Wiguna Rahman

wigu001@lipi.go.id

Extended author information available on the last page of the article 


\section{Introduction}

The Second Report on the State of the World's Plant Genetic Resources for Food and Agriculture asserted that the use of CWR in crop improvement programmes was increasing (FAO 2010). This increased level of use should continue as breeding techniques are improved, more published information on important traits in CWR becomes available, and the number of genebank accessions of CWR is increased (Hajjar and Hodgkin 2007). Plant breeders are attracted to use CWR as they provide a wide range of traits including adaptive traits to increase crop resilience in changing environments and to improve the yield and quality of crops (Hajjar and Hodgkin 2007; Maxted and Kell 2009; Dempewolf et al. 2017; Zhang et al. 2017). About 970 CWR have been used or recorded to have potential in crop improvement of 127 crops for specific traits such as: agronomic traits, abiotic and biotic stress, fertility, morphological, phenological and quality traits (Dempewolf et al. 2017).

Conservation of broad range of genetic diversity of CWR require a comprehensive conservation programmes. In the past, CWR conservation programmes were mostly focused on ex situ conservation. As a result, significant new accessions were added into ex situ collections, which now reach up to 7.4 million accessions of plant genetic resources, including CWR (FAO 2010). Today, about 1,750 genebanks are available around the world (FAO 2010). However, Castañeda-Álvarez et al. (2016) showed that $95 \%$ of global priority CWR are poorly represented in genebanks collections. On the other hand, in situ conservation programmes are only just getting global attention as a useful method for conserving CWR (Maxted 2003; Meilleur and Hodgkin 2004; Maxted and Kell 2009; Hunter and Heywood 2010; Bellon and Burdon 2017). This approach ensures the continued evolutionary adaptation of CWR to environmental changes and therefore continuing to shape their genetic diversity (Maxted et al. 2008a, b; Bellon and Burdon 2017). However, Vincent et al. (2019) showed that most of globally priority CWR are underrepresented in the global protected areas network.

Gap analysis is one of the steps in CWR conservation planning (Magos Brehm et al. 2017) and one of the known methods to increase representativeness of genetic diversity of CWR and also to provide guidance for further actions (Maxted et al. 2008a, b; Phillips et al. 2016; Parra-Quijano et al. 2012a, b). In this method, all CWR in ex situ collections are identified and compared to their natural habitat range within the country to evaluate the collections representativeness. In a similar way, in situ gap analysis evaluates the extent to which taxa distributions occur within existing protected areas and whether they are actively managed and monitored (Maxted et al. 2008a, b; RamírezVillegas et al. 2010; Phillips et al. 2016; Magos Brehm et al. 2017).

Indonesia is frequently considered as one of the most important regions for global and regional CWR (Vavilov 1935; Vincent et al. 2013, 2019; Castañeda-Álvarez et al. 2016). Banana, coconut, sugarcane, taro, and many tropical fruits were domesticated in this region (Vavilov 1935; van Steenis 1949). Vavilov (1935) stated that South East Asia (including Indonesia) is the centre of origin for at least 55 cultivated plant species. Recently, Vincent et al. (2013) included 84 taxa from Indonesia in the list of globally important CWR. Moreover, FAO (2017) highlighted Indonesia as among the top five of global producers of banana, coconut, mango, mangosteen, rice, and sugarcane. National systematic conservation planning of those wild relatives as part of sustaining the longterm conservation and production systems is therefore needed. 
This study aims to describe spatial distribution, evaluate the representativeness of current ex situ and in situ conservation programmes, and propose strategies for further conservation actions of priority CWR in Indonesia.

\section{Methods}

\section{Priority CWR taxa for Indonesia}

A recent inventory showed that 1968 taxa of wild relatives of food crops are found in Indonesia (Rahman et al. 2019). A prioritized subset of 234 taxa belonging to 36 genera, 52 crops, and 219 species were selected as priority CWR taxa for Indonesia. About 95 taxa related to nationally and globally important crops were set as primary priority taxa, 69 taxa related to nationally and regionally important crops were set as secondary priority taxa, and 70 taxa related to globally important crops but with less significant value at national level were defined as tertiary priority taxa (Table 1 ).

\section{Data collection}

Occurrence points for 234 priority CWR taxa were gathered from the Global Biodiversity Information Facility (GBIF) (www.gbif.org), herbarium specimens from herbarium Bogoriense (BO) (Bogor, Indonesia) and herbarium Naturalis Leiden (L) (Leiden, Netherlands), Genesys (https://www.genesys-pgr.org/), and literature (Table S1 in Supplementary Materials). Records that did not have geographic coordinates were georeferenced using online resources such as Cartographic Info (https://cartographic.info/names/place.php?state= id\&f=id), Mapcarta (https://mapcarta.com), and Papua Gazetteer (https://github.com/ rdmpage/papua-gazetteer/blob/master/papua_gazetter.tsv). Old herbarium specimens were georeferenced with guidance from collector journey history which is available on cyclopaedia of Malesian collectors (http://www.nationaalherbarium.n1/FMCollectors/). The presence points for 234 priority CWR were recorded and tabulated in MS Excel using the occurrence Data Collation Template (Magos Brehm et al. 2017). The accuracy of presence points of the present dataset was checked using the Geoqual tool in CAPFITOGEN (ParraQuijano 2016). Totalqual100 as a cumulative value of three parameters, that calculated the quality of occurence records based on the quality of geographic coordinates, suitability of the coordinates as habitat, and its accuration within the related administrative area, was used as the final parameter to determine the quality of occurence records. Only those with Totalqual100 values equal to 70-100 were used for further analysis to limit the accessions with unreliable records but still accomodate rare taxa that are only known from a single record. The administrative area at level district (ADM3) based on Global Administrative Areas (GADM) database version 2 (https://www.diva-gis.org/gdata) and global land cover (GLC 2000) (https://forobs.jrc.ec.europa.eu/products/glc2000/glc2000.php) were used to validate the occurence records.

\section{Predicted potential taxa distribution}

Species distribution modelling or environmental niche modelling was used to identify potential areas of occurrence since the national collecting and surveying programmes 


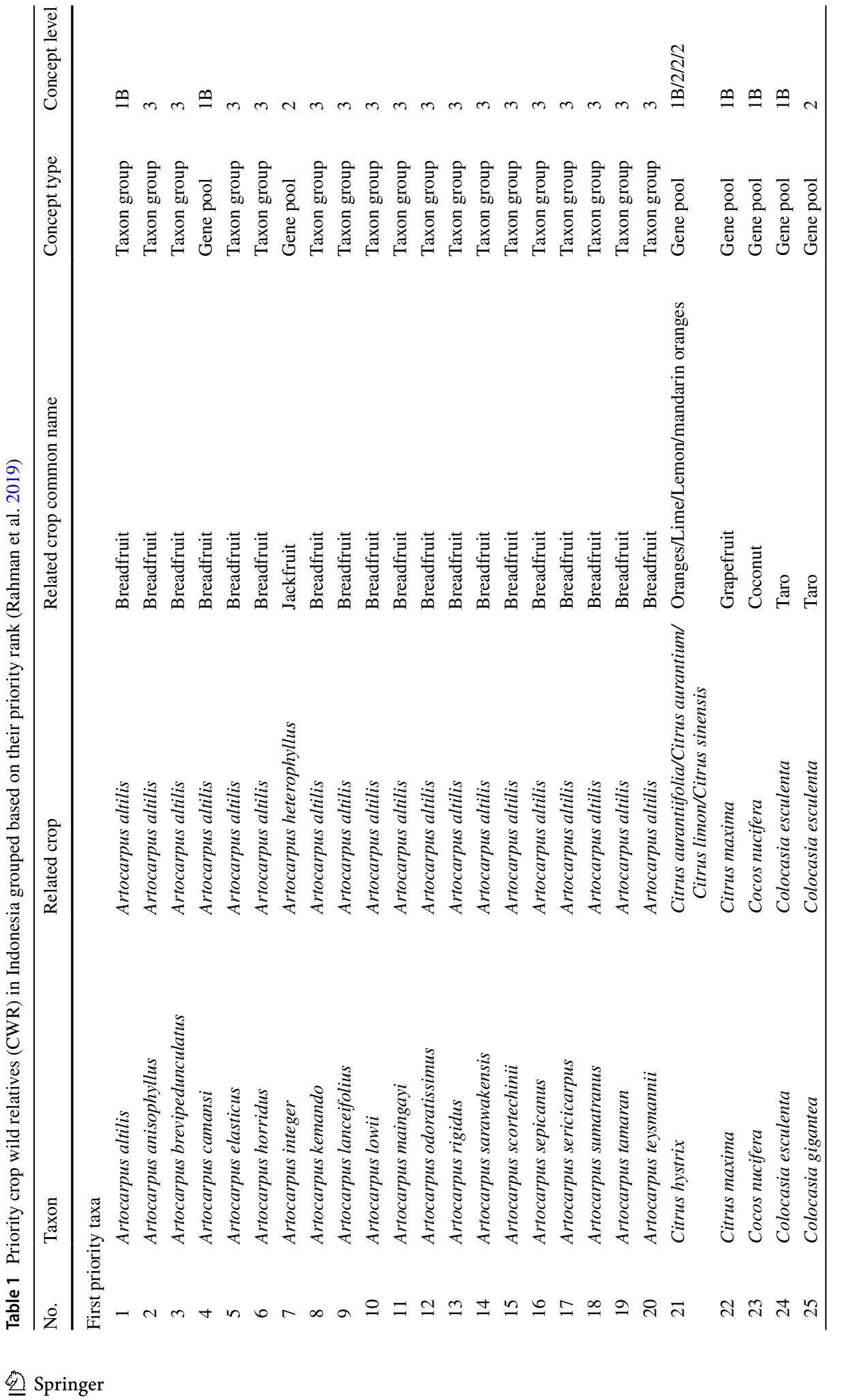




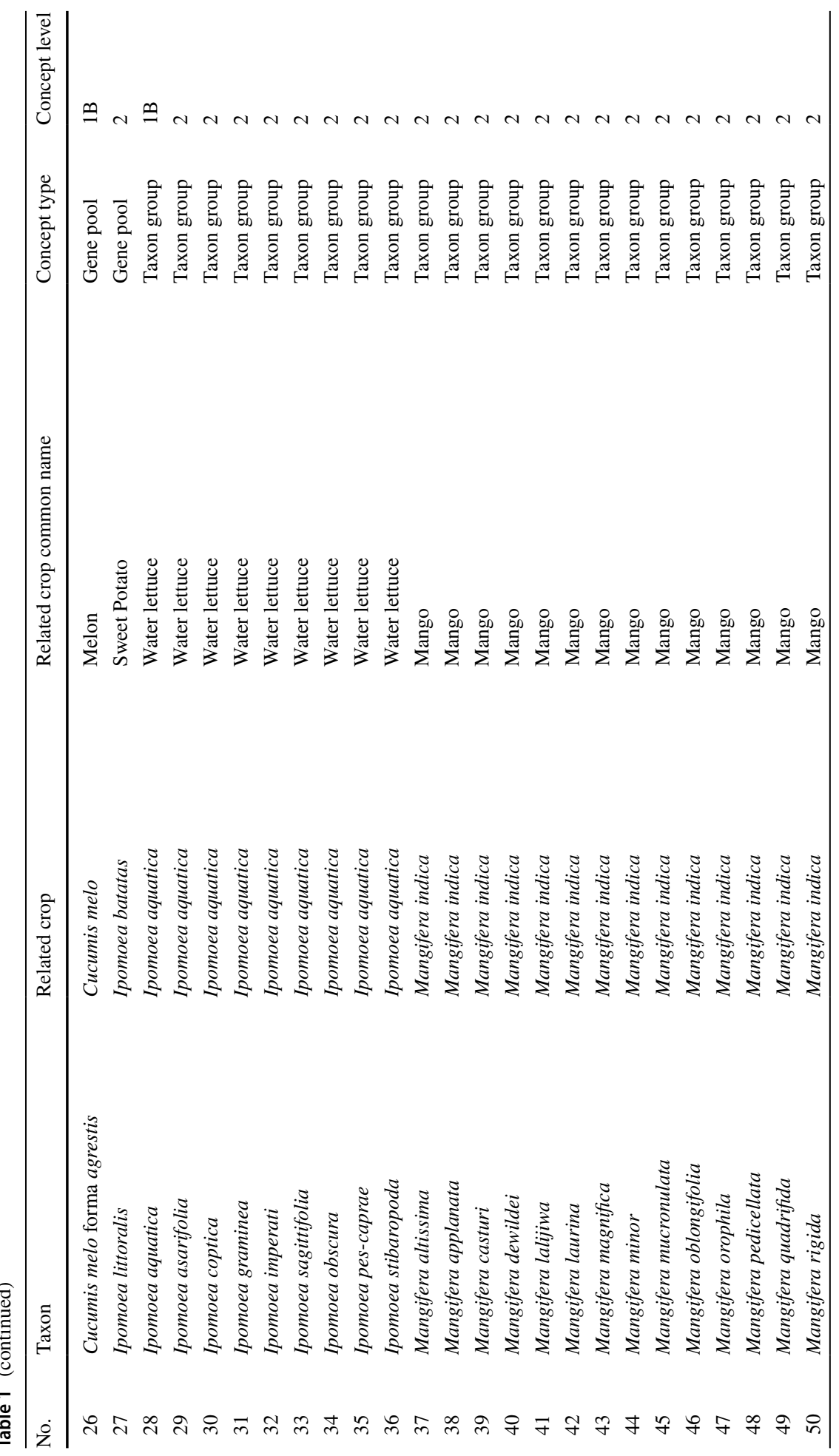




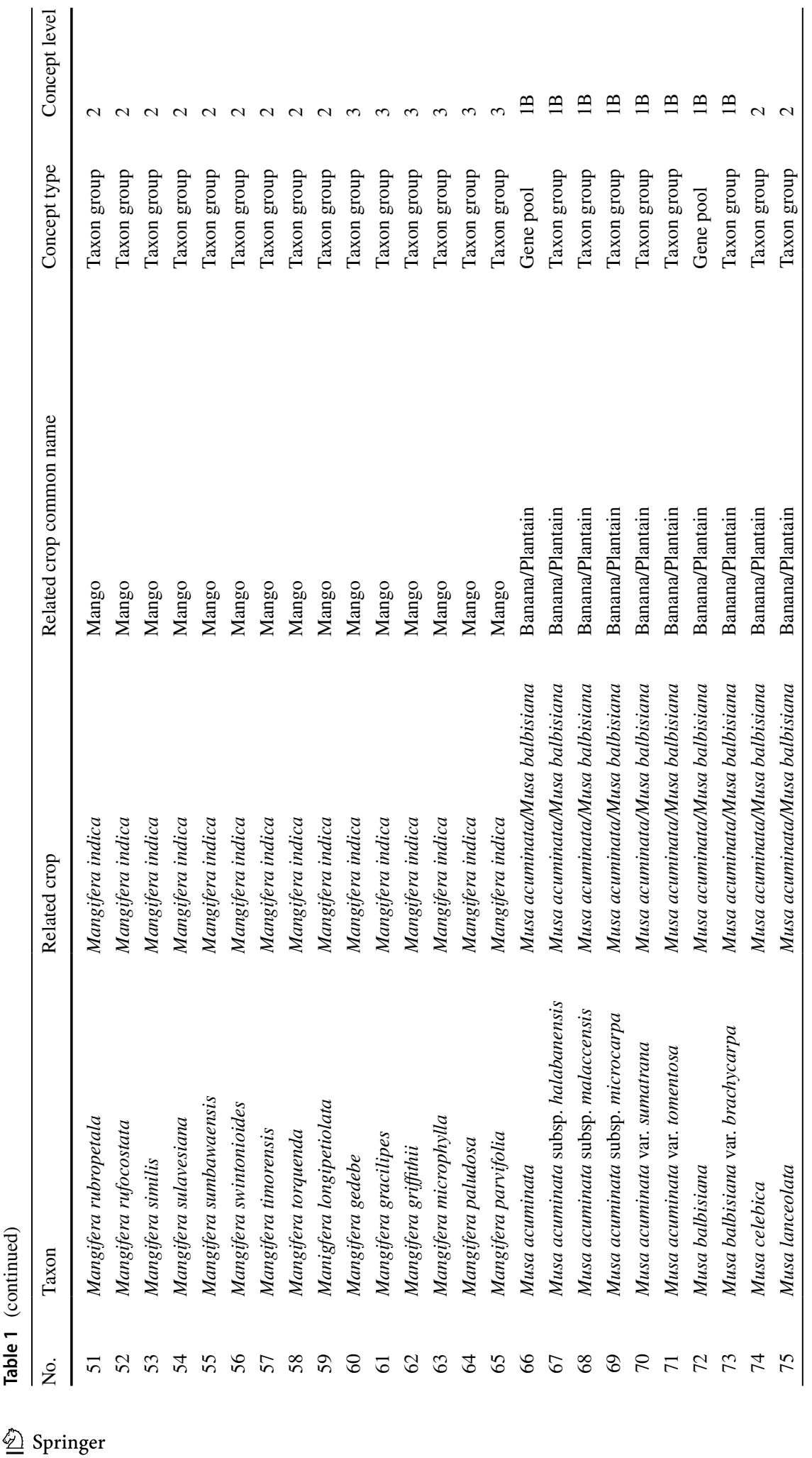




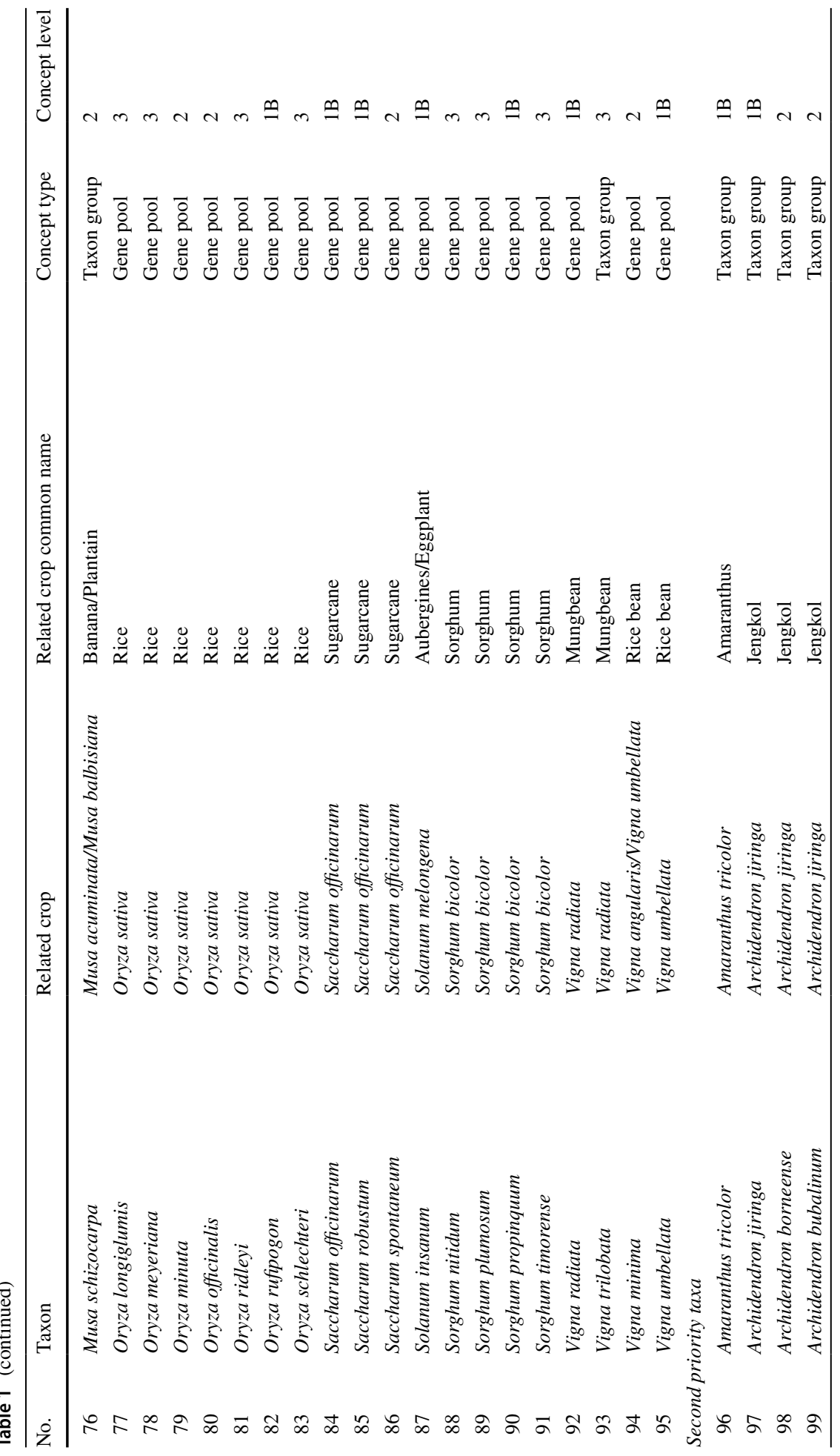




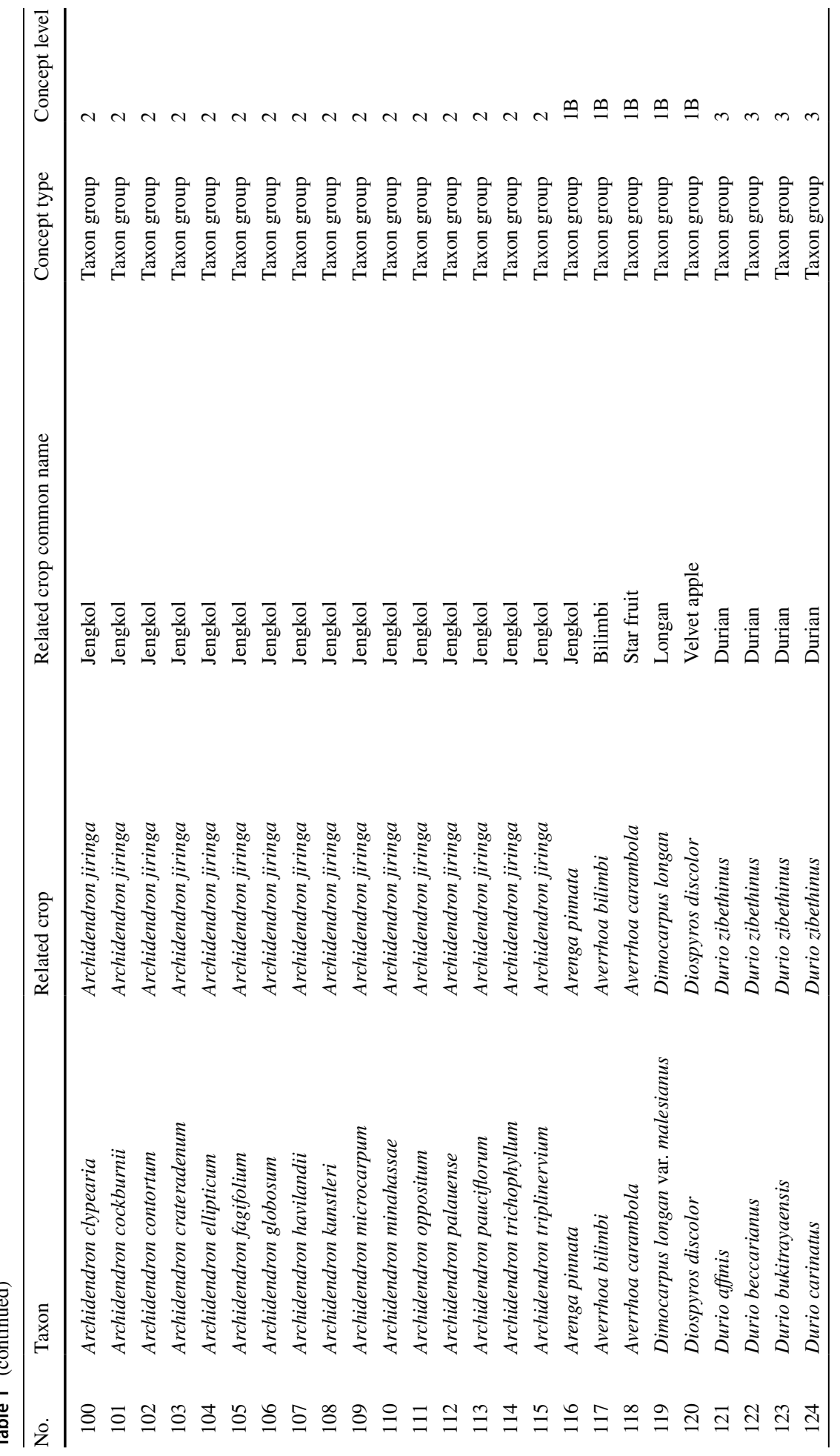




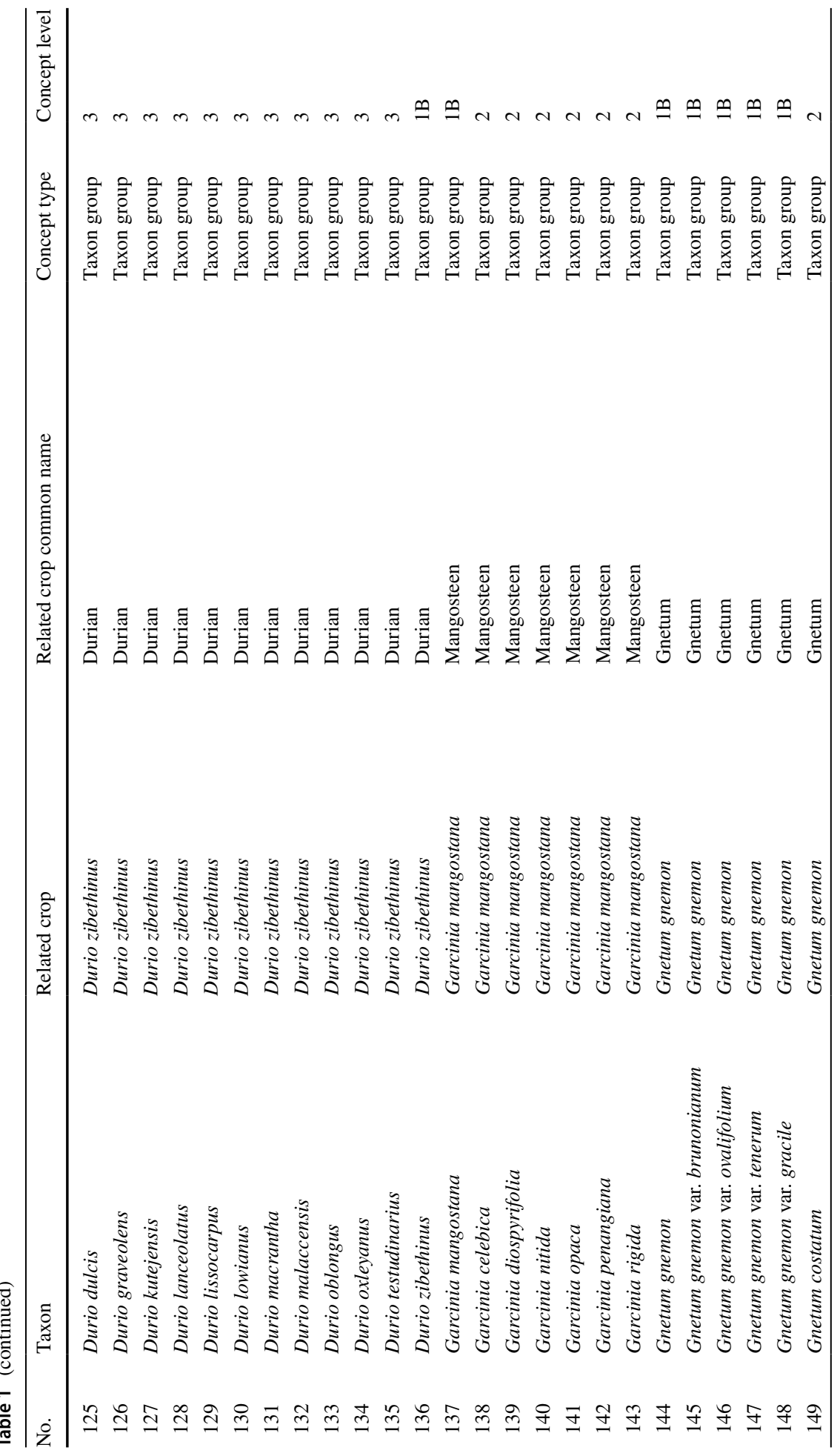




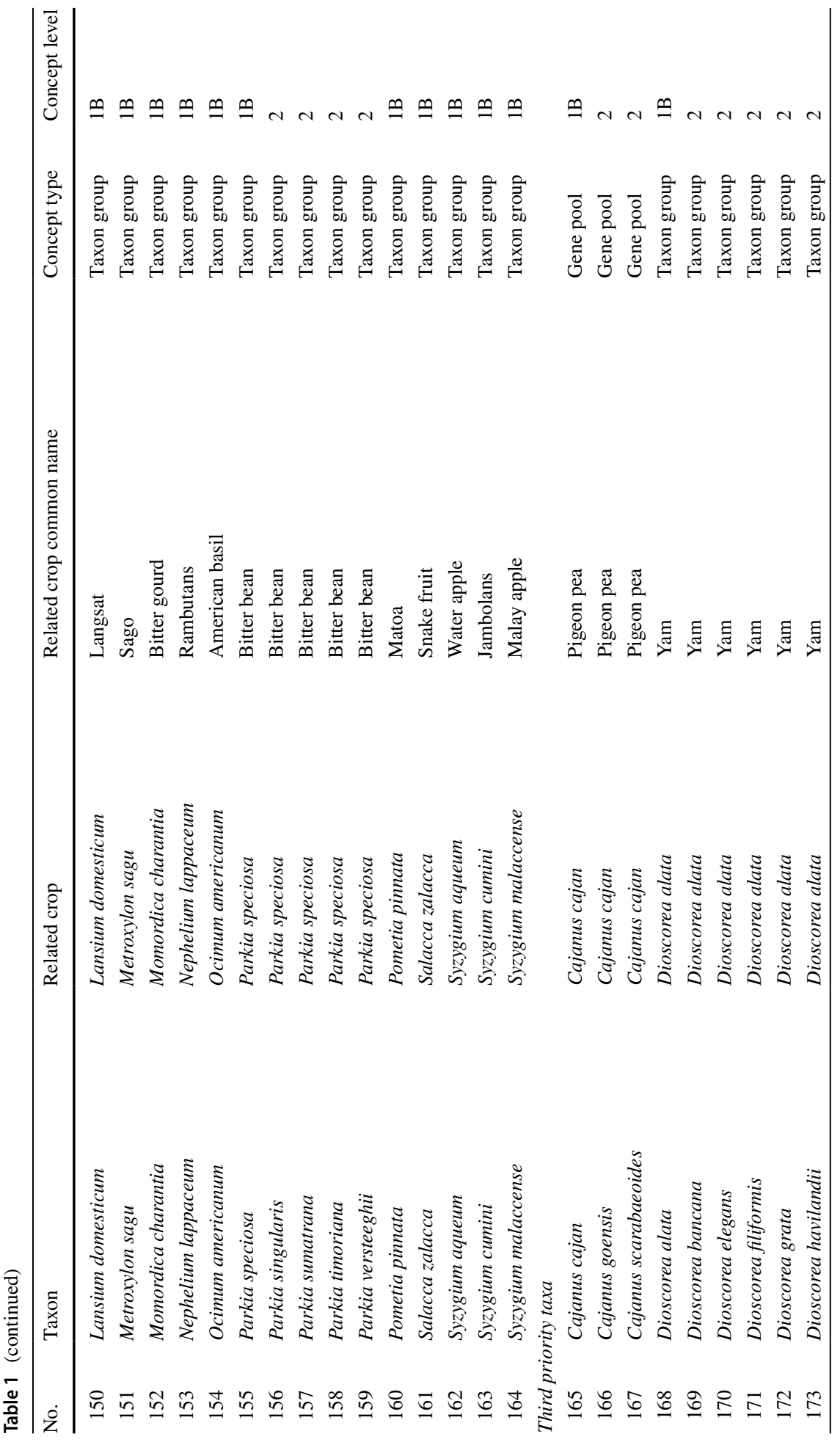




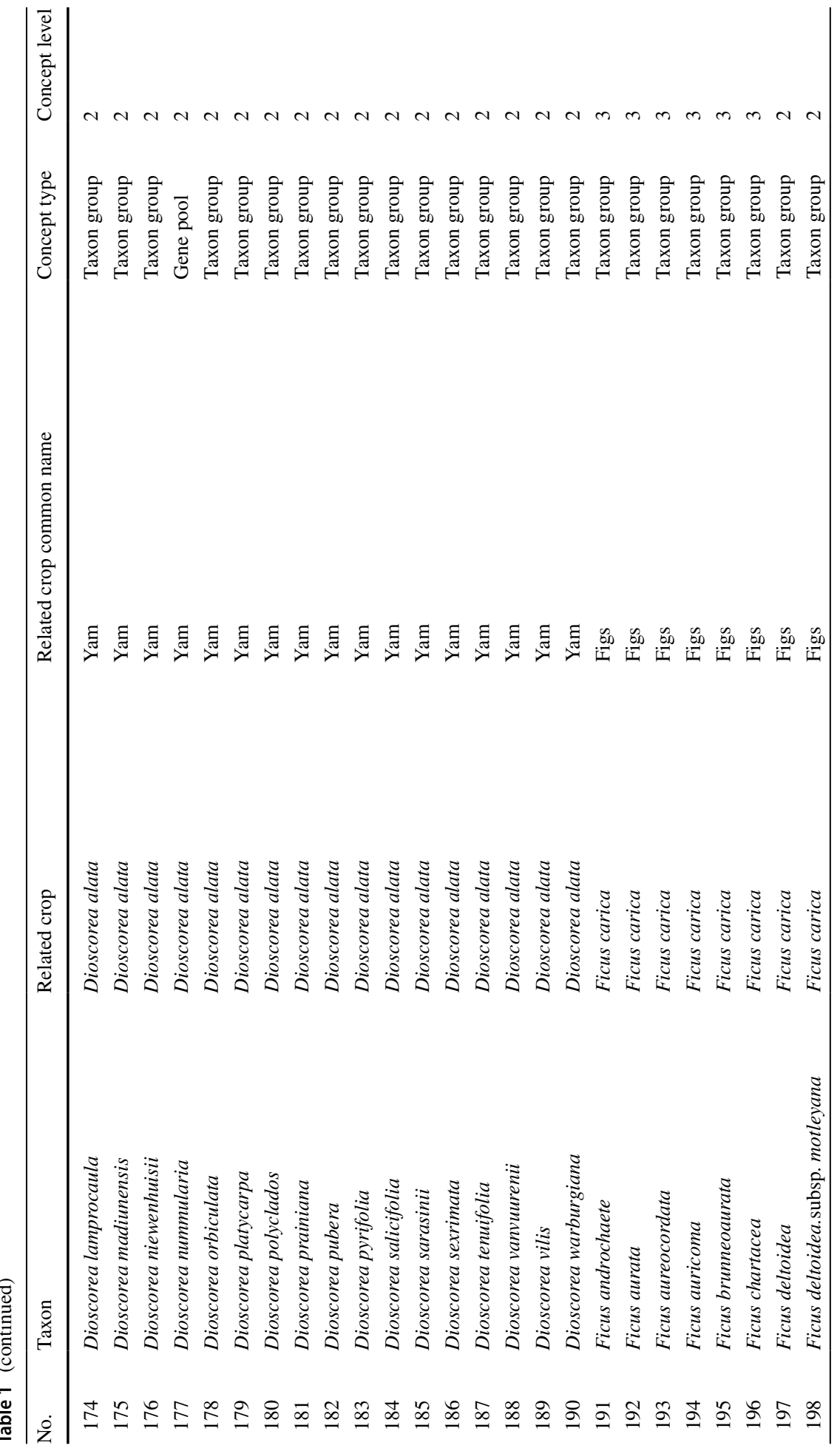




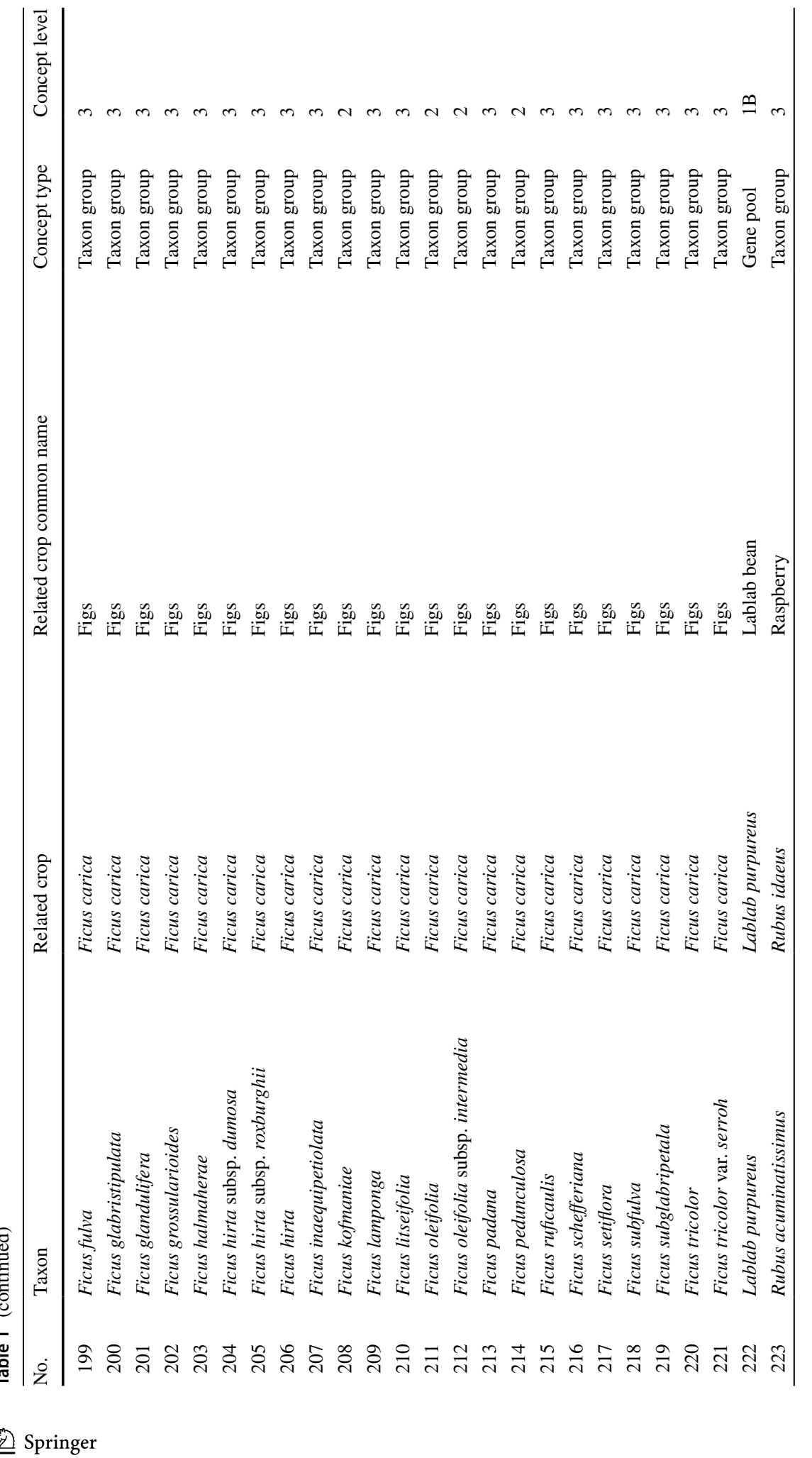




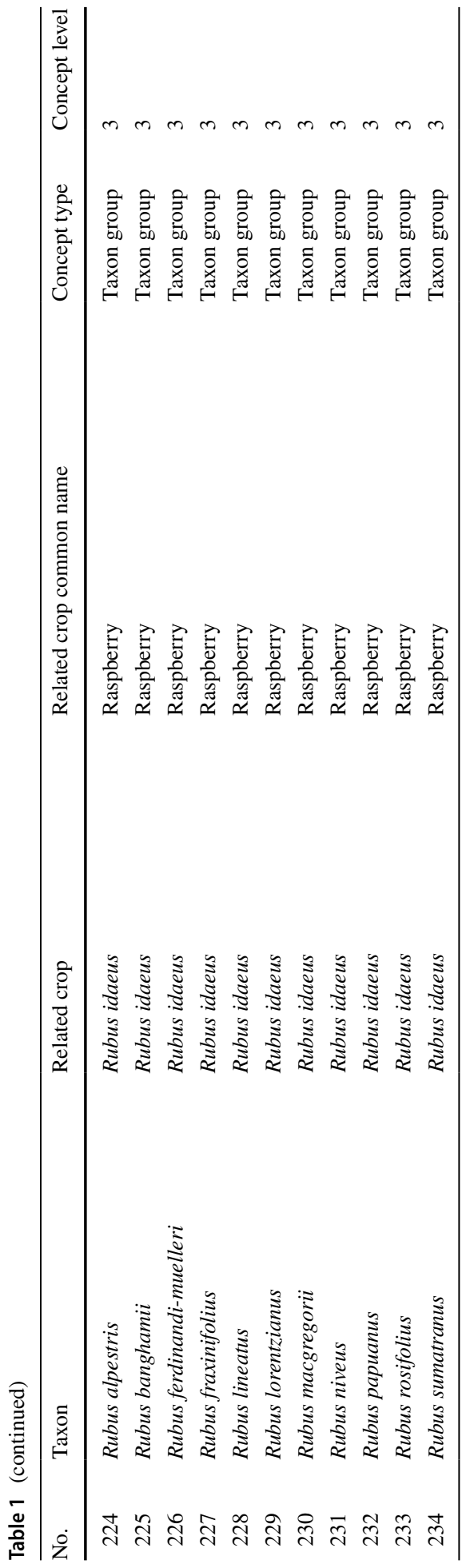


have not been systematically undertaken for all studied areas. Initially, 103 variables separated into three components (67 bioclimatic, 31 edaphic, and five geophysic variables) at $1 \times 1 \mathrm{~km}$ grid resolution were provided as predictors (as seen in Supplementary Materials Table S2). The SelectVar tool in CAPFITOGEN was then used to select the most important variable values for each taxon. In SelectVar, the value of environmental variables in each occurrence record were extracted and then used for further statistical analysis. A stepwise collinearity test with variation inflation factors (VIF) $<5$ was used. In addition, to prevent over prediction of the models, particularly for endemic island species, biogeographic units were used as an additional variable predictor as suggested by Raes et al. (2013). Each biogeographic units has a unique value that was used as a dispersal limitation predictor (Raes et al. 2013). The list of variables for each taxon to be used in the models can be seen in Table S3.

Maximum entropy algorithm (MaxEnt version 3.4.1k) (Phillips et al. 2018) was used to build species SDM for each priority taxon. The default setting was used to set the maximum number of background points (pseudoabsence) at 10,000 from the background extent within Indonesian territory. Maximum training sensitivity plus specificity was applied as the threshold rule (Liu et al. 2005) and cross-validation was used for resampling methods. Four replications for taxa with 10 to 30 presence points were used, while 5 and 10 replicates were used for taxa with 30 to 50 presence points and those with more than 50 presence points, respectively. To evaluate the accuracy and stability of the distribution models, three conditions were assessed: (i) average under the test receiver operating characteristics curve $\left(\mathrm{AUC}_{\text {test }}\right)>0.7$ (ATAUC $>0.7$ ), (ii) standard deviation of the ATAUC $<0.15$ (STAUC $<0.15$ ), and (iii) the proportion of potential distribution areas with STAUC $>0.15$, being $<10 \%$ (ASD15 $<10 \%$ ) as suggested by Ramírez-Villegas et al. (2010). Only taxa that met these criteria were considered to have accurate and stable models. The potential distribution area for taxa with presence points $<10$ or without accurate and stable models were estimated using a circular radius of $50 \mathrm{~km}$ around each presence point $\left(\mathrm{CA}_{50}\right)($ Hijmans and Spooner 2001). The list of taxa with valid SDM models and those estimated using $\mathrm{CA}_{50}$ are listed in Table S4.

\section{Ecogeographic land characterization (ELC) map}

There are two types of ELC maps, generalist and species-specific ELC maps. Generalist ELC maps are based on generalist ecogeographic variables, thus representing different landscape scenarios in a given area. While species-specific ELC maps are based on variables that were selected as being relevant in determining specific adaptive ecogeographic scenarios for single taxon (Parra-Quijano, et al. 2012a, b; Magos Brehm et al. 2016; Phillips et al. 2016; Contreras-Toledo et al. 2019). Only the generalist ELC map was calculated to accomodate those taxa with occurence records of less than 10, since those taxa do not have a species-specific ELC map. To generate a generalist ELC map, five variables per component (bioclimatic, geophysics, and edaphic component) of 103 environmental variables with $1 \times 1 \mathrm{~km}$ resolution were selected using the SelectVar tool in CAPFITOGEN. A stepwise collinearity test with variation inflation factors (VIF) $<5$ was used. Only variables with VIF less than 5 were selected. The selected variables for the generalist ELC map are: temperature seasonality (bio_4), annual temperature range (bio_7), precipitation during the coldest quarter (bio_19), average precipitation for April (prec_4), maximum temperature for January (tmax_1), top soil organic carbon content (t_oc), top soil sodicity (t_esp), top soil saturation of bases (t_bs), gravel content in top soil (t_gravel), top soil clay cation 
exchange capacity (t_cec_clay), elevation (alt), eastness, northness, aspect, and slope. Besides these 15 variables, biogeographic units, latitude and longitude were also used to reduce crosslinking (overlapping cells value between categories) among the ecogeographic units (Parra-Quijano 2016). The elbow method was then used for clustering the variables (to reduce complexity of cells to configure categories of ELC map) due to its ability to process large datasets for a large country more efficiently (Parra-Quijano et al. 2012a, b; Parra-Quijano 2016).

\section{In situ diversity analyses}

A map of predicted taxa richness areas for priority CWR in Indonesia was created by ensembling the predicted potential distribution maps of all studied taxa in ArcGIS 10.4.1. This predicted map was then overlayed to land cover the map produced by Tuanmu and Jetz (2014) to remove predicted distribution from urbanized and bare areas. Whilst for the observed taxa richness, it was based on all presence records for all priority taxa. In addition, a map showing areas with a high number of collections or biased map was also created. Both maps of observed taxa richness and number of records were created in DIVA-GIS ver.7.5.0 using a $50 \times 50 \mathrm{~km}$ grid cell size. Subsequently, the total number of populations and the number of populations within the existing protected area network were identified for each taxon. In this study, two presence points of the same taxon were defined as different populations when they were separated by at least $10 \mathrm{~km}$ using Complementa tool in Capfitogen (Parra-Quijano 2016).

The in situ ecogeographic diversity analysis was conducted based on the generalist ELC map. The ELC map can be a source for protected area managers at national levels and local levels to develop conservation programmes. The proportion of each ELC category within the existing PA network were compared to their total ELC category. Through the Representa tool in CAPFITOGEN, the frequency of each ELC categories were divided into four quartile classes: low $(<0.25)$, mid-low $(0.25-0.5)$, mid-high $(0.5-0.75)$, and high $(>0.75)$. The Representa tool is used to determine the representativeness of the total genetic diversity within the in situ sites and on the ex situ collections based on the ELC map. The representation of ELC categories within the in situ sites was conducted for all PAs network and the complementary areas.

A complementarity analysis that aims to prioritize areas for immediate conservation programmes with relative high effectiveness in terms of number of taxa conserved was conducted. The complementarity analysis used Rebelo's iterative method (Rebelo and Siegfried 1990) based on grid cells and on the existing PA network. In Rebelo's method, the site which contains the highest diversity will be ranked first, the subsequent sites were ranked by the number diversity of taxa not found in the previous rank. When the number of unique taxa of two sites were same, the total number of taxa were used to define the rank. The complementarity analysis was conducted through Complementa tool in CAPFITOGEN.

\section{Ex situ diversity analysis}

The ex situ accessions dataset was compiled from Genesys (https://www.genesys-pgr.org/), collections from four national botanic gardens in Indonesia (Bogor, Cibodas, Purwodadi, and Bali botanic gardens), and the Bioversity Collecting Missions Database (1978-1996) (http://bioversity.github.io/geosite/). Duplicated data from the Genesys and the Bioversity 
Collecting Missions Database were deleted for each taxa. The ex situ representativeness was assessed at both taxon and ecogeographic levels, using the Representa tool from CAPFITOGEN. The frequency of each ELC category was classified into quartile classes: low, mid-low, mid-high, and high. These frequencies were then used to defined the ex situ gap types of each ELC category ranging from 1 to 13, where 1 is the highest priority and 13 the lowest priority (Parra-Quijano 2016). By comparing the distribution of ex situ collections, in situ occurrence records and ELC map categories, a Chi-square test was performed to assess whether the collecting efforts were biased or not at 0.05 significance level to cover all genetic diversity of taxa. A map for a further collecting programme was produced by overlaying four maps with the same resolution $1 \times 1 \mathrm{~km}$. The maps are the buffered $10 \mathrm{~km}$ of the ex situ accessions record map, land cover map (Tuanmu and Jetz 2014), biodiversity intactness map with resolution $1 \times 1 \mathrm{~km}$ (Newbold et al. 2016), and the predicted taxa richness map. First, the predicted taxa richness map was subtracted by the buffered $10 \mathrm{~km}$ of the ex situ map. Then, it was overlayed on the land cover map and biodiversity intactness map. Grid cells with the highest score mean that cells contain the highest taxa diversity with high potential to present.

\section{In situ and ex situ conservation gap analyses}

In situ and ex situ conservation gap analyses followed Magos Brehm et al. (2017). In situ conservation gaps correspond to CWR taxa and their (ecogeographic) diversity not actively conserved in situ as well as CWR taxa that occur within protected areas but lack active management (no active conservation program). The ex situ conservation gap corresponds to both CWR taxa and their (ecogeographic) diversity is not adequately conserved ex situ.

\section{Results}

\section{Ecogeographic land characterization (ELC) map}

The ELC generalist map for priority CWR in Indonesia is shown in Fig. 1. The map contains 62 categories (from category 1 to 62). The average value for the environmental variables of each variable can be seen in the supplementary materials (Table S5 in supplementary materials). The most frequent category is category 16 that covers $11.07 \%$ of the generalist ELC map for Indonesia. Whilst the lowest occurrence category is category 42 that only $0.001 \%$ of total ELC generalist category (Table S6 in supplementary materials). Not all categories occurred in each of the seven biogeographic units (major islands group). Java and Sulawesi contained the most diverse ELC generalist categories with 54 and 48 ELC categories, respectively. While the Lesser Sunda Islands only contained 19 ELC categories. The details of distribution of ELC categories of the ELC generalist map for each biogeographic unit can be seen in Supplementary Materials (Figs. S1-S7). The raster data for those figure can be accessed in figshare (https://doi.org/10.6084/mg.figshare.14386268. $\mathrm{v} 1)$.

\section{In situ diversity}

In total, 8226 unique presence points for 234 priority CWR were compiled. The number of presence records for each taxon ranged from 1 to 259. About 83 taxa have occurrence 


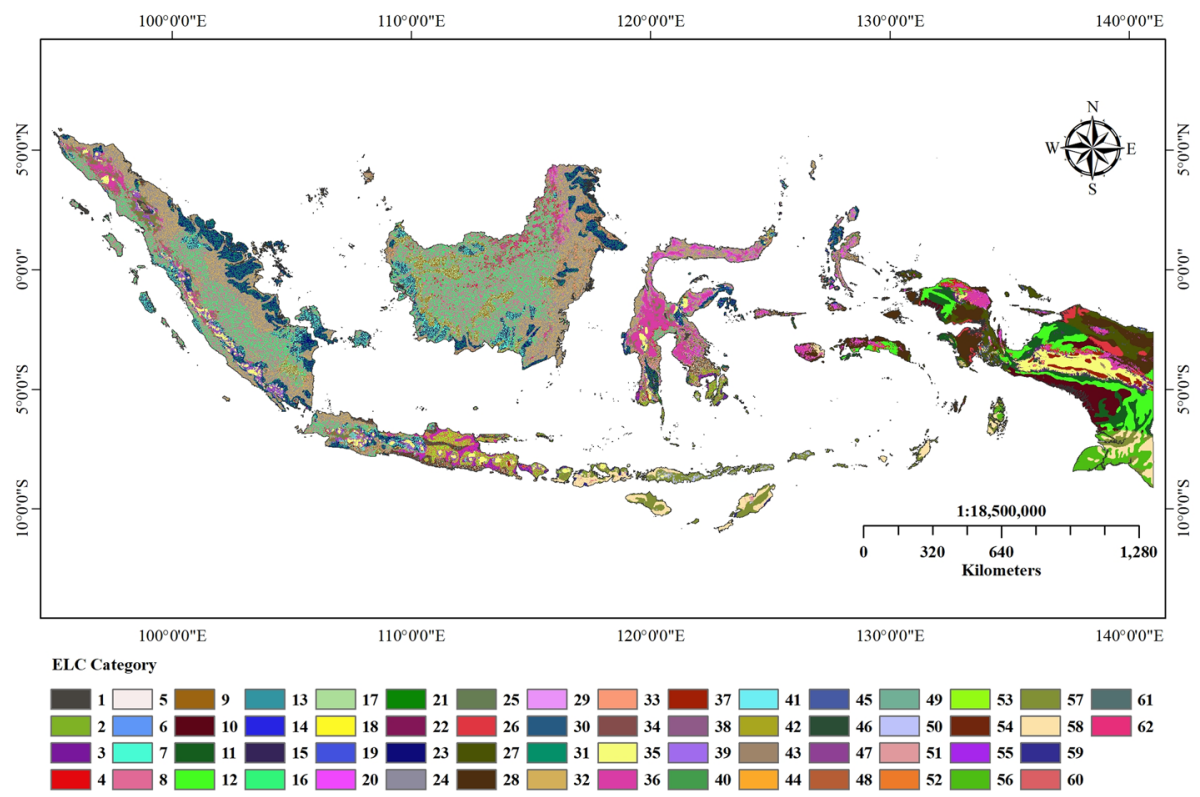

Fig. 1 Ecogeographic Land Characterization (ELC) generalist map of priority CWR in Indonesia

points for less than 10 records. Therefore, those 83 taxa were not included in the species distribution model. However, only 58 taxa have a valid model since the other 93 taxa did not pass the threshold value. Most of taxa with no valid model have a ASD15 value higher than $10 \%$. Therefore, the predicted distribution for taxa not included in the species distribution model and without a valid model were used in a Circular Area of $50 \mathrm{~km}$ (CA50).

The highest taxa richness areas of priority CWR based on the predicted distribution (Fig. 2A) and observed distribution (Fig. 2B) were found in Java, with the highest concentration in the West Java and Banten provinces. Several areas that contained significant numbers of priority CWR were also spotted outside Java such as in the North and West Sumatra provinces, East Kalimantan, North Sulawesi, and South Sulawesi. On the other hand, the Papua region contains the lowest diversity of priority CWR.

Based on the number of observations from areas where collections and expeditions were conducted, the island of Java was also identified as the most frequently surveyed (as seen in the number of observation maps in Fig. 2C), while large areas in the Papua region were still under-surveyed. Even though the collecting efforts were unequal across the country, predicted distribution models can be used to identify potential existing populations in those regions that are under-surveyed.

About 169 taxa have at least one known record within the existing PA network. The number of total priority CWR in protected area network in Indonesia can be seen in Table S7. Further analysis based on the predicted potential distribution model, showed that 60 out of the 65 taxa that do not have known records within the PA network have the potential to occur there (Table S8 in supplementary analysis). While the predicted distribution of five taxa, namely Dioscorea tenuifolia (wild relative of yam), Ficus auricoma, F. halmaherae, F. subglabritepala (wild relatives of figs), and Musa acuminata subsp. microcarpa (wild relative of banana), do not overlap with any PA within the existing PA network. 


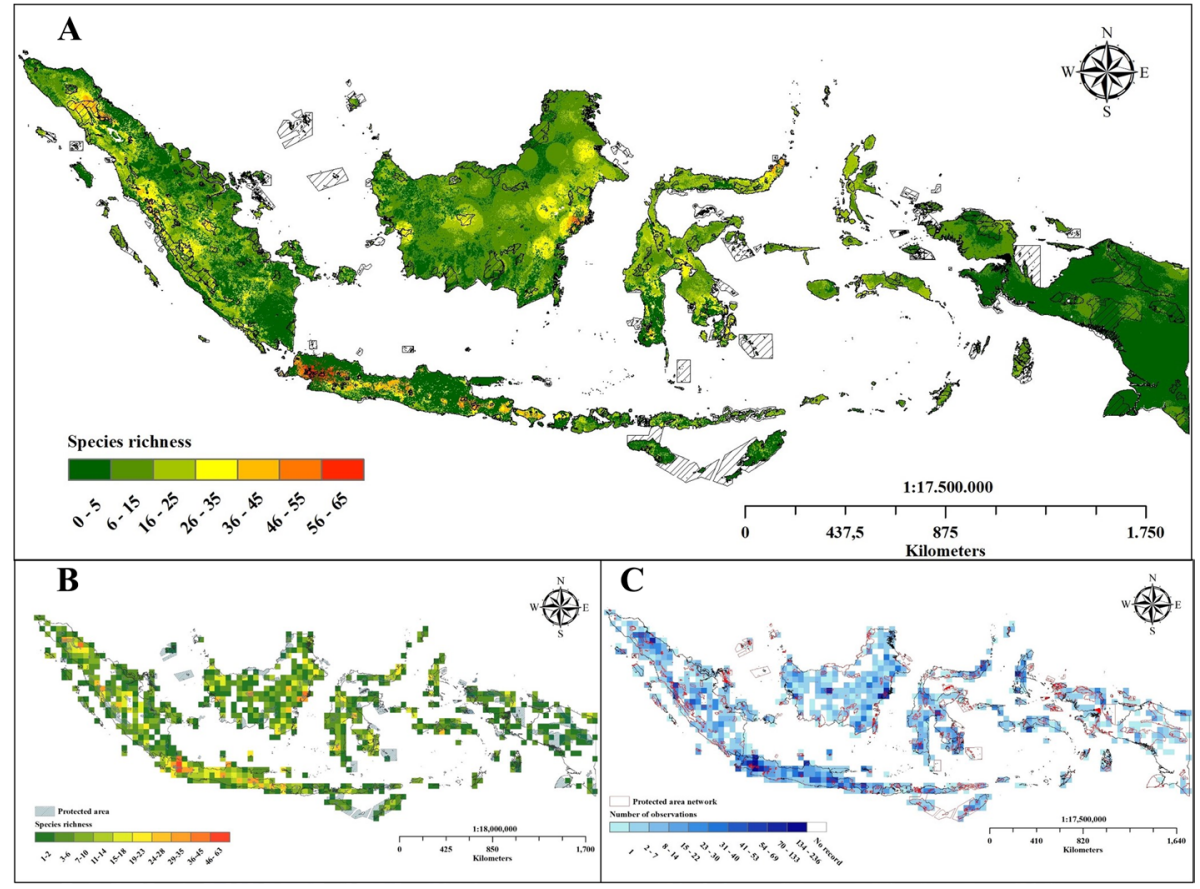

Fig. 2 Taxa richness maps based on predicted distribution (A) and observed records (B) and number of observations $(\mathbf{C})$ of priority CWR taxa in Indonesia

Most of taxa do not have enough ecogeographic representativeness within the existing protected areas. Only 62 taxa have more than 50\% of their ecogeographic diversity within the existing protected areas. The in situ ecogeographic diversity of each taxon based on the generalist ELC map ranged from 1 to 39 categories. Gnetum gnemon (wild relative of gnetum) has the diverse in situ ecogeographic diversity with 39 ELC categories area, while 29 taxa were recorded to have only one ELC category (Table S9 in supplementary materials). On average, all of the ELC categories for each taxon are underrepresented in the existing PA network.

Sixty one complementary grid cells $(50 \times 50 \mathrm{~km})$ are required to conserve all priority CWR taxa (Fig. 3) and the top 11 are enough to cover 2/3 of priority taxa (Table 2). Within the top eleven complementary grids, two are located in both Java and Sulawesi, three are in both Sumatra and Kalimantan, and one in Timor. The full list of complementary grids can be seen in Table S10 in supplementary materials. Artocarpus elasticus (wild relative of breadfruit) is the most frequent taxon in the complementary grid network found in 22 grids. However, Archidendron clypearia (wild relative of jengkol) is found in 18 grids with a higher number of recorded populations within the complementary grids (Table S8); whilst 162 taxa were found in less than five complementary grids and 92 taxa were found in only one. At ecogeographic level, eleven ELC categories of the ELC generalist map (category 2, 6, 14, 18, 21, 34, 38, 42, 46, 52, and 56) were absent in the complementary grids (Table S6 in supplementary materials). Complementary grids ranking 3 that were found in North Sulawesi contained the highest diversity of ELC categories and contained 31 priority taxa. Whilst the number of ELC 


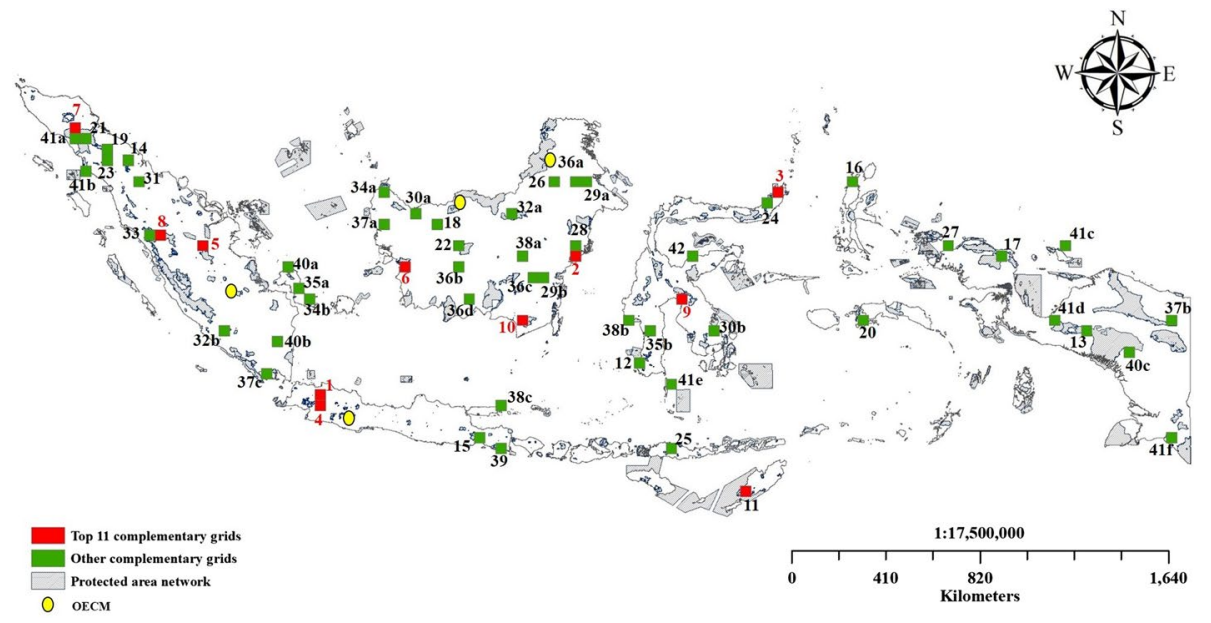

Fig. 3 Complementary area based on complementary grid cells $(50 \times 50 \mathrm{~km})$ for 234 priority CWR taxa in Indonesia. The number indicates the rank of the complementary grid. The first rank has the highest number of taxa and the subsequent rank has the highest additional taxa compared to the previous complementary grid. Letters following the number mean that those grids have the same total number of taxa and were ranked alphabetically. The yellow circles are some of established conservation areas categorized as Other Effective Area-Based Conservation Measures (OECMs)

Table 2 The 11 complementary grids $(50 \times 50 \mathrm{~km})$ needed to conserve in situ two-thirds of the priority CWR taxa in Indonesia

\begin{tabular}{lllll}
\hline $\begin{array}{l}\text { Complementary } \\
\text { grid rank }\end{array}$ & Additional taxa & Total taxa & $\begin{array}{l}\text { Cumulative } \\
\text { unique taxa }\end{array}$ & Province \\
\hline 1 & 54 & 54 & 54 & Banten, Jakarta Raya, West Java \\
2 & 30 & 46 & 84 & East Kalimantan \\
3 & 17 & 31 & 101 & North Sulawesi \\
4 & 12 & 46 & 113 & West Java \\
5 & 11 & 27 & 124 & Riau \\
6 & 8 & 25 & 132 & West Kalimantan \\
7 & 7 & 30 & 139 & Aceh \\
8 & 5 & 26 & 144 & Riau, West Sumatra \\
9 & 5 & 22 & 149 & South Sulawesi, South East Sulawesi \\
10 & 5 & 19 & 154 & South Kalimantan \\
11 & 5 & 13 & 159 & East Nusa Tenggara \\
\hline
\end{tabular}

categories in the top rank of complementary grids was only twelve (Table S10 in supplementary materials).

In addition, 40 complementary protected areas were identified to conserve the 169 priority CWR that have known records within the protected area (PA) network (Fig. 4). Mt. Leuser NP in Aceh and North Sumatra provinces was identified as the top complementary PA containing populations of 48 priority taxa (Table 3). The distribution of unique CWR taxa within the top ten of complementary PAs can be seen in the Fig. S8 


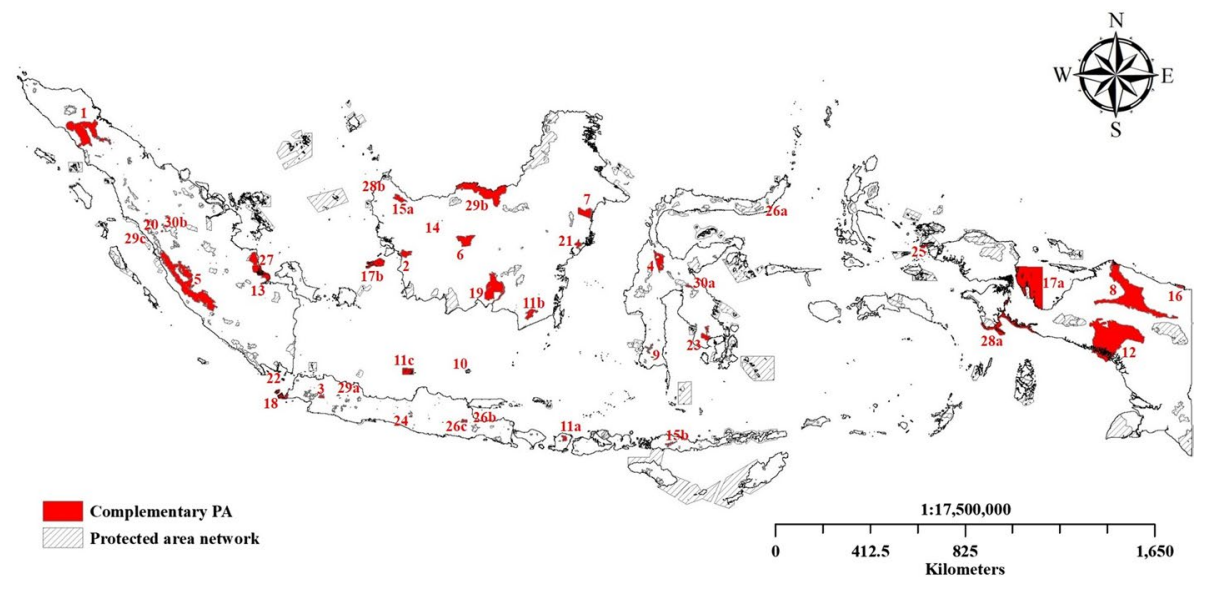

Fig. 4 Complementary protected area network for 169 priority CWR taxa having at least one known population record within the protected area network in Indonesia. The number indicates the rank of the complementary area. The first area has the highest number of taxa and the subsequent number has the highest additional taxa compared to previous complementary area. Letters following the number mean that those grids have the same total number of taxa and were ranked alphabetically

Table 3 Top 10 complementary PA proposed as genetic reserves for CWR in Indonesia

\begin{tabular}{llllll}
\hline $\begin{array}{l}\text { Comple- } \\
\text { mentary PA } \\
\text { rank }\end{array}$ & Additional taxa & Total taxa & $\begin{array}{l}\text { Cumulative } \\
\text { unique taxa }\end{array}$ & Protected area & Province \\
\hline 1 & 48 & 48 & 48 & Mt. Leuser NP & Aceh, North Sumatra \\
2 & 19 & 30 & 67 & Mt. Palung NP & West Kalimantan \\
3 & 13 & 27 & 80 & Mt. Gede-Pangrango NP & West Java \\
4 & 8 & 17 & 88 & Lore Lindu NP & Central Sulawesi \\
5 & 7 & 23 & 95 & Kerinci Seblat NP & Bengkulu, Jambi, \\
& & & & West Sumatra, \\
& 7 & 22 & 102 & Bukit Baka-Bukit Raya & West Kalimantan, \\
6 & 6 & 12 & 108 & Kutai NP & Central Kalimantan \\
7 & 5 & 13 & 113 & Memberamo Foja WR & East Kalimantan \\
8 & 5 & 10 & 118 & Bantimurung NRP & South Sulawesi \\
9 & 4 & 12 & 122 & P. Bawean WR & East Java \\
10 & & & & &
\end{tabular}

$N P$ National Park, WR Wildlife Reserve, NRP National Recreation Park

in supplementary material. Additionally, the complete list of the 40 complementary PAs can be found in Table S11 in supplementary material. Pometia pinnata (wild relative of matoa) is the most frequent taxon across the complementary PA network occurring in 14 complementary PAs (Table S12 in supplementary material). In terms of ecogeographic level, ten ELC categories of ELC generalist map (category 2, 5, 14, 18, 22, $30,34,38,42$, and 46) were absent in complementary PA (Table S6 in supplementary materials). 


\section{Ex situ diversity}

Around $34 \%$ of the 234 priority CWR (80 taxa) are represented in ex situ collections. Within the ex situ collections, only three taxa (Durio zibethinus, Oryza officinalis, and Oryza rufipogon) were collected from more than 50 different populations. Oryza rufipogon, the closest wild relative of rice, has the highest accessions number of ex situ accessions.

The ecogeographic representativeness of the accessions for most of those taxa with ex situ collections was low when compared to their distribution range. In similar way, the ex situ accessions were unevenly distributed within the ELC categories of the ELC generalist map (ecogeographical gaps) (Table S13 in supplementary materials). Based on the result of a chi-square test of the distribution of accesssions in the ex situ collection compared to the in situ diversity and the ELC categories, the collecting effort for most of the current ex situ accessions were not biased or over-collected from the same ELC category. Collecting effort bias was found on 36 of 80 taxa with ex situ collections. This means that most of accesssions in the ex situ collection of those taxa came from the same ELC category. Table S9 and S13 (in supplementary materials) can be used as a guidance for selecting PAs as collecting site targets to enhance the ex situ collections.

\section{In situ and ex situ gap analysis}

In situ gap analysis identified 65 taxa occurring outside the existing protected area network exclusively (Table S14 in Supplementary materials). Whilst 169 taxa have records within existing protected areas but lack conservation management, i.e. they are passively conserved. Based on ecogeographic diversity, most of taxa are not adequately represented in the existing protected areas. Only nine of the 234 taxa have full representation of their ecogeographic diversity within the existing protected areas.

On the other hand, ex situ gap analysis identified 154 (66\%) taxa not adequately conserved ex situ. Moreover, most priority taxa do not have their ecogeographic diversity adequately conserved ex situ, except for Durio macrantha. (wild relative of durian), that has one single ex situ accession from the only one known location from where this species was described. However, its ecogeographic class was categorized as low representation and its mean required more ex situ accessions. Priority areas for further collection for ex situ conservation has a similar pattern as the predicted distribution richness of priority taxa as shown in Fig. 5.

\section{Discussion}

Ex situ and in situ conservation gaps for priority CWR at global level have been identified by Castañeda-Álvarez et al. (2016) and Vincent et al. (2013, 2019). However, further analyses are required to identify the species or gaps for conservation programmes at national level since the management of these resources and other natural resources is of national responsibility. Therefore, conservation of CWR should be in conjunction with other national conservation and wealth development programmes (Magos Brehm et al. 2017). The results proposed here report on the representativeness of these national priority CWR in current ex situ and in situ conservation programmes in Indonesia. 


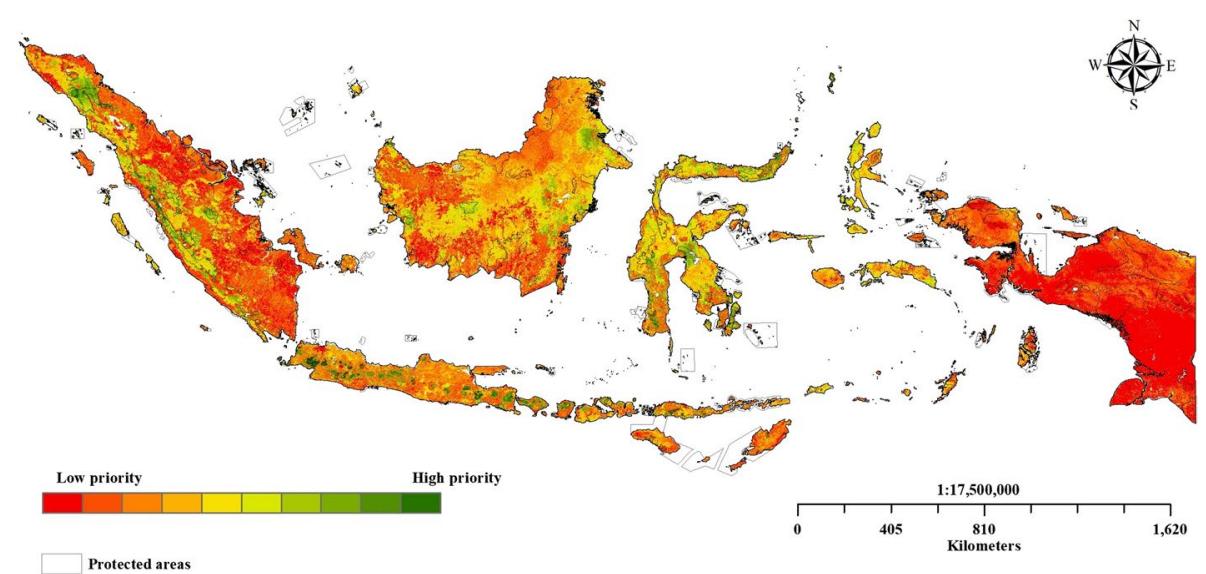

Fig. 5 Priority areas for further ex situ collecting programs of priority CWR in Indonesia

The distribution map of priority CWR in Indonesia revealed that Java, Kalimantan, Sumatra, and Sulawesi contained the richest areas for their diversity. Java was identified to contain a high degree of prority CWR diversity, particularly the western part. In Sumatra, the richest areas were identified in the northern and western parts. In Kalimantan (Indonesian Borneo), the diversity was concentrated in the eastern part, particularly at the mouth of Mahakam river area around Samarinda. In Sulawesi, the northern and southern parts of Sulawesi were the richest areas. It seems that the richest areas of CWR in Indonesia were in congruence with the global biodiversity hotspots. Sumatra, Java, and Kalimantan were situated in the Sundaland and Sulawesi in Wallacea, two areas that were defined as global biodiversity hotspots (Myers et al. 2000; Mittermeier et al. 2011). Therefore, those CWR richness areas can be defined as CWR diversity hotspots in Indonesia.

The results show that Java is the richest area and contains the highest priority taxa densities for further collection of ex situ conservation. However, Dsikowitzky et al. (2019) stated that the island is the most populous and the natural ecosystem has been more severely affected by land conversion compared to other islands in Indonesia. The question is why does Java contain more priority CWR taxa. Is it merely caused by the fact that it is better surveyed than the other islands which can be seen in the biased observation map (Fig. 2C)? Van Welzen et al. (2011) found that based on floristic similarity, the flora of Java is more related to the Wallacea and Philippines flora than that of Sumatra and Borneo. Further investigation showed that the western part of Java is much more related to the Sundaland flora (Borneo, Sumatra, and Malay Peninsula), while the eastern part of Java is more related to the Wallacean flora (Van Welzen and Raes 2011). It seems that this evidence caused the percentage of endemic flora in Java is the lowest in Malesia (floristic area that cover Indonesia, Malaysia, Brunei, Philippines, Singapore, and Papua New Guinea) (van Welzen et al. 2011). In consequence, many widely distributed or non-endemic taxa can be found in Java, including the priority CWR taxa. Moreover, the ELC generalist map shows that the ecogeographic diversity in Java is more diverse than other areas in Indonesia.

However, to propose priority areas for conservation of biodiversity, a strategy that merely focuses on species richness areas is not an effective approach since this approach is driven by widespread species and neglects those that urgently need conservation action 
(Brooks et al. 2006). To cope with this insufficiency, complementarity analysis is frequently used (Fielder et al. 2015; Phillips et al. 2016; Contreras-Toledo et al. 2019). The result of complementarity analysis of priority CWR in Indonesia shows that complementary grids or complementary PAs are not only located in the CWR hotspots in Indonesia. Forty complementary grids are located in Sundaland, 13 in Wallacea, and eight in Papuasia. Whilst, 27 complementary PAs were found in Sundaland, 7 in Wallacea, and 6 in Papuasia.

Based on the World Database for Protected Areas (PAs), about 733 protected areas are recorded in Indonesia (https://protectedplanet.net). Only 175 of these have records of priority CWR. 40 of those were identified as complementary sites for 169 priority taxa that have records within the existing PAs. Based on predicted distribution, 23 taxa were predicted to occur in more than 300 different existing protected areas in Indonesia, including those 175 PAs. One problem that still poses a challenge within the existing PA areas is the effectiveness of conservation management of these areas in terms of biodiversity conservation. In Indonesia, "paper parks", i.e. protected areas that are encroached by illegal logging or farm expansion activities, is a known problem (Curran 2004; Gaveau et al. 2007). However, there were increasing positive trends in the effectiveness of protected areas on biodiversity and ecosystems conservation in Indonesia, between 2015 and 2017, for the 398 existing PAs which have management effectiveness evaluation (Ariyanto et al. 2017). While the other protected areas have not yet been evaluated.

Since the aim of CWR conservation is capturing the maximum genetic diversity for crop improvement, proposed priority conservation areas should also be considered for their genetic diversity coverage. Genetic diversity can be predicted based on ecogeographic diversity (Korona 1996). The ELC map developed by Parra-Quijano et al. (2012a, b) aims at describing different potential plant adaptation scenarios based on the ecogeographic diversity of CWR taxa. The results show that only seven of 62 ELC categories, based on the ELC generalist map, not have a representation in the existing protected areas. Eleven and ten ELC categories were also missing in the complementary sites in both grid cells based and protected area based, respectively. On average, the ELC categories diversity for each taxon in complementary grid cells (48.52\%) was higher compared to those in all existing protected area (36.66\%) or complementary PA (28.86\%) (Table S9 in supplementary data). This evidence is consistent for the coverage of different populations for each taxon, where on average, the complementary grid cells (35.29\%) cover higher populations than all existing PAs (16.26\%) and complementary PA (11.32\%) sites (Table S8 in supplementary data). It shows that not all priority taxa have suitable environments inside the protected areas. Maxted and Kell (2009) stated that most protected areas tend to conserve the climax communities while most CWR were found in pre-climax communities. In fact, some wild relatives, particularly non-tree species, such as wild relatives of amaranth, basil, melon, rice, sugarcane, sorghum, or taro, are found frequently in anthropogenic areas such as road sides, field edges, or abandoned cultivated areas. Even though complementary protected areas may not conserve all genetic diversity of priority taxa, these results provide baseline information for a minimum set of priority conservation areas, extend the coverage of existing PA, and/or make informal in situ conservation areas (conservation areas managed by local people without legal documents and management from the government). Therefore, complementary PAs can be set up as the initial priority areas for effective conservation of CWR in Indonesia since they have formal legal recognition for long-term conservation.

Aichi targets 11 recognizes the importance of conservation areas outside the protected areas (UNEP 2010). Other Effective Area-Based Conservation Measures (OECMs), i.e. geographical areas other than protected areas for long term in situ conservation of 
biodiversity and related ecosystem services, are a good option (CBD 2018). Therefore, for those 65 taxa without known records within existing protected areas, complementary grids could be nominated as OECMs, after further field surveys are conducted. Even though OECMs can provide positive outcomes for CWR conservation, their implementation, like other conservation efforts, are challenged by limited resources (Jonas et al. 2018). With massive problems faced by the existing PAs in Indonesia, the development of OECMs for CWR will require a lot of effort from all related stakeholders. However, there are examples of sites managed by local traditional tribes in Indonesia which could be defined as OECMs, for example: the sacred forest of Dayak Iban in West Kalimantan (Wadley and Colfer 2004), tana' ulen or restricted forested land of Dayak Kenyah in North Kalimantan (Eghenter 2018) and the sacred forest of the Naga community in West Java (Irawan et al. 2019). OECMs can also be developed by private sectors or organizations (Jonas et al. 2018). The Harapan rainforest in Sumatra is probably an example of OECMs that was established by a consortium of conservation organisations in Indonesia (Utomo and Walsh 2018). Fourteen tree taxa of priority CWR were recorded in the Harapan rainforest. Utomo and Walsh (2018) noted that at least 820 tree species occurred in this forest. The locations of those four OECMs can be seen in Fig. 3. This means that the development of OECMs for priority CWR in Indonesia has potential prospects.

As part of comprehensive CWR conservation planning, the ex situ plays an important and complementary role in in situ conservation. Ex situ conservation techniques include seed storage, field genebank, in vitro storage, cryopreservation, botanic gardens and arboreta, pollen storage, or DNA storage (Maxted et al. 1997; Engels et al. 2008). Based on the catalogue of national crop genebanks in Indonesia (BB-Biogen 2019), most of priority CWR taxa do not have any accessions in the national agricultural genebanks. Most of their collections are primarily landraces. This evidence was highlighted by Hawkes et al. (2000) who asserted that landraces are easier to collect as they have cultivated populations within farms. About $25 \%$ of ex situ collections of Indonesia priority CWR were deposited and recorded at international institutions such as IRRI, Bioversity international, AVRDC, or CIAT (https://www.genesys-pgr.org/). Those ex situ collections mainly conserved plants with orthodox seeds. While the ex situ collections of perennials, particularly trees, are mostly found in botanic gardens (75\%) (Table S15 in supplementary material. O'Donnell and Sharrock (2018) stated the importance of botanic gardens in conjunction with agricultural genebanks in conservation of CWR. Four established botanic gardens in Indonesia have conserved 66 priority CWR taxa in Indonesia. The list of botanic gardens in Indonesia with the number of collections of priority CWR and total accessions can be seen in Table S16 in supplementary material.

A combination of different techniques should be used to get an adequate ex situ conservation of priority CWR taxa in Indonesia. Taxa with orthodox seeds type such as grass taxa (Oryza spp., Saccharum spp., and Sorghum spp.), pulses (Cajanus spp., Lablab spp. and Vigna spp.), Amaranthus spp. and Ocimum spp., should be prioritized for institutions with seedbanks. In vitro techniques can be applied for wild relatives of banana and taro, since these techniques have been successfully used for such taxa (MusaNet 2016; Ebert and Waqainabete 2018). Perennials with recalcitrant seeds, particularly trees, are recommended to be conserved in field genebanks or botanic gardens. Eleven Indonesian institutions maintain field genebanks for plant genetic resources for food and agriculture (PGRFA), among which, four have already conserved some priority CWR in Indonesia (Indonesian authorities for the second report of the state of PGRFA 2010). Indonesian national report in the second report of the state of PGRFA (2010) highlighted the differences between field genebanks and botanic gardens. In field 
genebanks, the number of maintained taxa are limited but their genetic diversity is high. While botanic gardens maintain many taxa but their genetic diversity is generally low since their number of accessions are relatively small compared to field genebanks.

Based on the results of this paper, seven recommendations to strengthen the conservation programmes of priority CWR taxa in Indonesia are proposed:

1. For in situ programs, complementary PAs should be a priority to establish a network of genetic reserves for CWR populations in Indonesia. By linking the conservation of CWR diversity and general biodiversity within the complementary PAs, active conservation management of priority CWR will have equal attention. The top ten complementary PAs (Mt. Leuser NP, Mt. Palung NP, Mt. Gede-Pangrango NP, Lore Lindu NP, Kerinci Seblat NP, Bukit Baka-Bukit Raya NP, Kutai NP, Mamberamo Foja WR, Bantimurung NRP, and P. Bawean WR) can be prioritized for the genetic reserves of CWR in Indonesia.

2. Further field surveys for the 65 taxa without any records within the existing protected area network are strongly proposed. The highest priority are the five taxa that are not predicted to be found within the existing PA network. Priority protected areas for future field surveys are those in the surroundings of presence records or those for which CWR presence has been predicted but not confirmed. For those taxa that has been predicted to present within the existing PAs network, the priority PAs for further field surveys are Mt. Mangkol GFP (Bangka Island), Kayan Mentarang NP (North Kalimantan), Lati Petangis GFP (East Kalimantan), Sungai Kapuas and Tanjung Malatayur (Central Kalimantan), and Aketajawe Lolobata NP (North Moluccas).

3. It is suggested that Other Effective Area-Based Conservation Measures (OECMs) are used for taxa that are not found within the PA network and for non-forest taxa (preclimax community species). The locations for potential OECMs of priority CWR taxa are the complementary grids where these taxa are found. For example, the OECMs can be established in North Halmahera in the Moluccas (complementary grid rank 16), Berau (complementary grid rank 29a and 36a) and the Malinau area (complementary grid rank 26) of East Kalimantan, the border areas of East Kalimantan and South Kalimantan (complementary grid rank 29b), Sorong in West Papua (complementary grid rank 27), Labuhan Batu-Tapanuli Selatan of North Sumatra (complementary grid rank 31 ), or Bangka Selatan in Bangka Island (complementary grid rank 34b). Coordination between stakeholders and relevant local communities where the OECMs will be established is strongly advised to get the appropriate applied management.

4. In terms of ex situ programmes, the priority for further collecting missions are the 154 taxa without any ex situ collections. The priority areas for this action are Mt. Leuser NP (Aceh), Arau Hilir and Air Terusan WR (West Sumatra), Mt. Halimun-Salak NP (West Java), Mt. Palung NP (West Kalimantan), and Faruhumpenai NR (South Sulawesi).

5. To increase the current accession number of taxa with ex situ collections, the ecogeographic diversity representativeness is suggested as a guide. The area with priority gap types can be used as a guidance as seen in Table S13. The priority area will be specific for each taxa. For example, Archidendron clypearia, the priority gap type was found in Memberamo Foja WR, Pulau Kobror WR, Pulau Dolok WR, Karimata NR, Lorentz NP, Muara Kaman Sedulang NR, Tasik Belat WR and Wasur NP.

6. Enhance the diversity of ex situ techniques (arboreta and botanic gardens, cryopreservation, field genebanks, in vitro culture, pollen storage, and seed banks) to optimize the 
safety of long-term ex situ conservation. Institutions with specialized ex situ techniques should be in coordination for efficient conservation efforts.

7. The in situ and ex situ conservation achievement progress should be communicated to the stakeholders periodically to evaluate the effectiveness and efficiency of the CWR conservation programmes. In this context, the national agricultural genebanks can act as the major player.

\section{Conclusion}

The diversity and in situ and ex situ conservation gaps for 234 priority CWR in Indonesia were identified in this paper. 169 priority taxa have at least one population record within the existing protected area network. The other 60 taxa were predicted to occur in several existing PAs, while the existence of five other taxa (Dioscorea tenuifolia (wild relative of yam), Ficus auricoma, Ficus halmaherae, Ficus subglabripetala (wild relatives of figs), and Musa acuminata subsp. Microcarpa (wild relative of bananana)) should get the most attention by undertaking immediate field surveys. Complementary analysis, which identified at least 61 complementary grids, are required to conserve all priority CWR and 40 complementary PAs to conserve 169 priority taxa, those with records within the PA network. Complementary PA should be prioritized to initiate the development of a genetic reserve network of priority CWR in Indonesia. OECMs for priority CWR taxa should also be considered to complement the CWR PA network. Only 80 taxa have records within the current ex situ collections. Since all taxa with ex situ collections have spatial and ecogeographical gaps, all priority CWR taxa require further collecting programs. However, those 154 taxa without any ex situ collections should be prioritized for future collecting missions.

Supplementary Information The online version contains supplementary material available at https://doi. org/10.1007/s10531-021-02225-4.

Acknowledgements We acknowledge The Ministry of Research and Technology of Republic Indonesia for the scholarship to W. Rahman.

Author contributions Conceived and designed the study: WR, JMB, NM; Data collation and preparation: WR; Georeferencing the herbarium information: WR and MF; Method development: WR, ARC, MPQ; Interpreted the result: WR, J.M.B.; Wrote the paper: WR; critically reviewed the paper: WR, JMB, NM, JP.

\section{Declarations}

Conflict of interest There are no conflicts of interest.

Open Access This article is licensed under a Creative Commons Attribution 4.0 International License, which permits use, sharing, adaptation, distribution and reproduction in any medium or format, as long as you give appropriate credit to the original author(s) and the source, provide a link to the Creative Commons licence, and indicate if changes were made. The images or other third party material in this article are included in the article's Creative Commons licence, unless indicated otherwise in a credit line to the material. If material is not included in the article's Creative Commons licence and your intended use is not permitted by statutory regulation or exceeds the permitted use, you will need to obtain permission directly from the copyright holder. To view a copy of this licence, visit http://creativecommons.org/licenses/by/4.0/. 


\section{References}

Ariyanto AC, Sulastriningsih D, Risdianto D, et al (2017) Efektivitas pengelolaan kawasan konservasi di Indonesia tahun 2017. Direktorat Kawasan Konservasi. Direktorat Jenderal Konservasi Sumber Daya Alam dan Ekosistem. Kementrian Lingkungan Hidup dan Kehutanan

BB-Biogen (2019) Katalog data paspor SDG tanaman pangan (Data passport catalogue of food crops genetic resources)

Bellon MR, Burdon JJ (2017) In situ conservation-harnessing natural and human-derived evolutionary forces to ensure future crop adaptation. Evol Appl 10:965-977. https://doi.org/10.1111/eva.12521

Brooks TM, Mittermeier RA, da Fonseca GAB et al (2006) Global biodiversity conservation priorities. Science 313:58-61. https://doi.org/10.1126/science.1127609

Castañeda-Álvarez NP, Khoury CK, Achicanoy HA et al (2016) Global conservation priorities for crop wild relatives. Nat Plants 2:16022. https://doi.org/10.1038/nplants. 2016.22

CBD (2018) Protected areas and other effective area-based conservation measures. Draft recommendation submitted by the Chair

Contreras-Toledo AR, Cortés-Cruz M, Costich DE et al (2019) Diversity and conservation priorities of crop wild relatives in Mexico. Plant Genet Resour Charact Util 17:140-150. https://doi.org/10. 1017/S1479262118000540

Curran LM (2004) Lowland forest loss in protected areas of Indonesian Borneo. Science 303:10001003. https://doi.org/10.1126/science.1091714

Dempewolf H, Baute G, Anderson J et al (2017) Past and future use of wild relatives in crop breeding. Crop Sci. https://doi.org/10.2135/cropsci2016.10.0885

Dsikowitzky L, Damar A, Ferse SCA, et al (2019) Java Island, Indonesia. In: World seas: an environmental evaluation, 2nd edn. Elsevier, pp 459-490

Ebert AW, Waqainabete LM (2018) Conserving and sharing taro genetic resources for the benefit of global taro cultivation: a core contribution of the centre for pacific crops and trees. Biopreserv Biobank 16:361-367. https://doi.org/10.1089/bio.2018.0017

Eghenter C (2018) Indigenous effective area-based conservation measures: conservation practices among Dayak Kenyah of North Kalimantan. PARKS 24:69-78

Engels JMM, Maggioni L, Maxted N, Dulloo ME (2008) Complementing in situ conservation with ex situ measures. In: Iriondo JM, Maxted N, Dulloo ME (eds) Conserving plant genetic diversity in protected areas: population management of crop wild relatives. CAB International, pp 169-181

FAO (2010) The second reports on the state of the world's plant genetic resources for food and agriculture. Commision on Genetic Resources for Food and Agriculture. FAO, UN. Rome

FAO (2017) Crop Statistics. http://www.fao.org/faostat/en/\#data/QC. Accessed 15 Feb 2018

Fielder H, Brotherton P, Hosking J et al (2015) Enhancing the conservation of crop wild relatives in England. PLoS ONE 10:e0130804. https://doi.org/10.1371/journal.pone.0130804

Gaveau DLA, Wandono H, Setiabudi F (2007) Three decades of deforestation in southwest Sumatra: have protected areas halted forest loss and logging, and promoted re-growth? Biol Conserv 134:495-504. https://doi.org/10.1016/j.biocon.2006.08.035

Hajjar R, Hodgkin T (2007) The use of wild relatives in crop improvement: a survey of developments over the last 20 years. Euphytica 156:1-13. https://doi.org/10.1007/s10681-007-9363-0

Hawkes JG, Maxted N, Ford-Lloyd BV (2000) The ex situ conservation of plant genetic resources. Kluwer Academic Publishers, Dordrecht

Hijmans R, Spooner D (2001) Geographic distribution of wild potatoe species. Am J Bot 88:2101-2112

Hunter D, Heywood V (2010) Crop wild relatives a manual of in situ conservation. Bioversity International, Rome

Indonesian authorities for the second report of the state of PGRFA (2010) Country report on the state of plant genetic resources for food and agriculture: Indonesia. Italy, Rome

Irawan B, Partasasmita R, Rahayu N et al (2019) Indigenoust knowledge of bamboos by Naga community, Tasikmalaya District, West Java, Indonesia. Biodiversitas J Biol Divers 20:1423-1434. https:// doi.org/10.13057/biodiv/d200535

Jonas HD, MacKinnon K, Dudley N, et al (2018) Editorial essay: other effective area-based conservation measures: from Aichi target 11 to the post-2020 biodiversity framework. PARKS 9-16

Korona R (1996) Adaptation to structurally different environments. Proc R Soc Lond Ser B Biol Sci 263:1665-1669. https://doi.org/10.1098/rspb.1996.0243

Liu C, Berry PM, Dawson TP, Pearson RG (2005) Selecting thresholds of occurrence in the prediction of species distributions. Ecography (cop) 28:385-393. https://doi.org/10.1111/j.0906-7590.2005. 03957.x 
Magos Brehm J, Saifan S, Taifour H et al (2016) Crop wild relatives, a priority in Jordan? Developing a national strategy for the conservation of plant diversity in Jordan using a participatory approach. In: Maxted N, Dulloo M, Ford-Lloyd B (eds) Enhancing crop genepool use: capturing wild relative and landrace diversity for crop improvement. CAB International, Wallingford, pp 172-188

Magos Brehm J, Kell S, Thormann I, et al (2017) interactive toolkit for crop wild relatives conservation planning version 1.0. University of Birmingham, Birmingham, UK and Bioversity International, Rome

Maxted N (2003) Conserving the genetic resources of crop wild relatives in European protected areas. Biol Conserv 113:411-417. https://doi.org/10.1016/S0006-3207(03)00123-X

Maxted N, Kell S (2009) Establishment of a global network for the in situ conservation of crop wild relatives: status and needs

Maxted N, Ford-Lloyd BV, Hawkes JG (1997) Complementary conservation strategies. In: Maxted N, Ford-Lloyd BV, Hawkes JG (eds) Plant genetic conservation the in situ approach. Chapman\&Hall, pp 15-39

Maxted N, Dulloo E, Ford-Lloyd V et al (2008a) Gap analysis: a tool for complementary genetic conservation assessment. Divers Distrib 14:1018-1030. https://doi.org/10.1111/j.1472-4642.2008. 00512.x

Maxted N, Iriondo JM, Dulloo ME, Lane A (2008b) Introduction: The integration of PGR conservation with protected area management. In: Iriondo JM, Maxted N, Dulloo ME (eds) Conserving plant genetic diversity in protected areas: population management of crop wild relatives. CAB International, Wallingford, pp 1-22

Meilleur BA, Hodgkin T (2004) In situ conservation of crop wild relatives: status and trends. Biodivers Conserv 13:663-684

Mittermeier RA, Turner WR, Larsen FW et al (2011) Global biodiversity conservation: the critical role of hotspots. Biodiversity hotspots. Springer, Berlin, pp 3-22

MusaNet (2016) Global strategy for the conservation and use of Musa (Banana) Genetic Resources. Bioversity International, Montpellier

Myers N, Mittermeier RA, Mittermeier CG et al (2000) Biodiversity hotspots for conservation priorities. Nature 403:853-858. https://doi.org/10.1038/35002501

Newbold T, Hudson LN, Arnell AP et al (2016) Has land use pushed terrestrial biodiversity beyond the planetary boundary? A global assessment. Science 353:288-291. https://doi.org/10.1126/science. aaf 2201

O’Donnell K, Sharrock S (2018) Botanic gardens complement agricultural gene bank in collecting and conserving plant genetic diversity. Biopreserv Biobank 16:384-390. https://doi.org/10.1089/bio. 2018.0028

Parra-Quijano M (2016) Tools CAPFITOGEN: program strengthen capabilities in national plant genetic resources program in Latin America Version 2.0. FAO

Parra-Quijano M, Iriondo JM, Torres E (2012a) Improving representativeness of genebank collections through species distribution models, gap analysis and ecogeographical maps. Biodivers Conserv 21:79-96. https://doi.org/10.1007/s10531-011-0167-0

Parra-Quijano M, Iriondo JM, Torres E (2012b) Ecogeographical land characterization maps as a tool for assessing plant adaptation and their implications in agrobiodiversity studies. Genet Resour Crop Evol 59:205-217. https://doi.org/10.1007/s10722-011-9676-7

Phillips J, Asdal A, Magos Brehm J et al (2016) In situ and ex situ diversity analysis of priority crop wild relatives in Norway. Divers Distrib 22:1112-1126. https://doi.org/10.1111/ddi.12470

Phillips SJ, Dudík M, Schapire RE (2018) Maxent software for modeling species niches and distributions (Version 3.4.1)

Raes N, Saw LG, van Welzen PC, Yahara T (2013) Legume diversity as indicator for botanical diversity on Sundaland, South East Asia. South African J Bot 89:265-272. https://doi.org/10.1016/j.sajb. 2013.06.004

Rahman W, Magos Brehm J, Maxted N (2019) Setting conservation priorities for the wild relatives of food crops in Indonesia. Genet Resour Crop Evol 66:809-824. https://doi.org/10.1007/ s10722-019-00761-1

Ramírez-Villegas J, Khoury C, Jarvis A et al (2010) A gap analysis methodology for collecting crop genepools: a case study with Phaseolus beans. PLoS ONE. https://doi.org/10.1371/journal.pone. 0013497

Rebelo AG, Siegfried WR (1990) Protection of Fynbos vegetation: ideal and real-world options. Biol Conserv 54:15-31. https://doi.org/10.1016/0006-3207(90)90039-R

Tuanmu M-N, Jetz W (2014) A global 1-km consensus land-cover product for biodiversity and ecosystem modelling. Glob Ecol Biogeogr 23:1031-1045. https://doi.org/10.1111/geb.12182 
UNEP (2010) Decision adopted by the conference of theparties to the convention on biological diversity at its tenth meeting X/2. The Strategic Plan for Biodiversity 2011-2020 and the Aichi Biodiversity Targets

Utomo AB, Walsh TA (2018) Hutan Harapan ecosystem restoration concession, Sumatra, Indonesia: a potential OECM? PARKS 24:61-68

van Steenis CGGJ (1949) General Considerations. Flora Malesiana Series I,:XIII-LXIX

Van Welzen WPC, Raes N (2011) The floristic position of Java. Gard Bull Singapore 63:329-339

van Welzen PC, Parnell JAN, Slik JWF (2011) Wallace's Line and plant distributions: two or three phytogeographical areas and where to group Java? Biol J Linn Soc 103:531-545. https://doi.org/10. $1111 / \mathrm{j} .1095-8312.2011 .01647 . x$

Vavilov NI (1935) The phytogeographical basis for plant breeding. Theor Basis Plant Breed 1:17-75

Vincent H, Wiersema J, Kell S et al (2013) A prioritized crop wild relative inventory to help underpin global food security. Biol Conserv 167:265-275. https://doi.org/10.1016/j.biocon.2013.08.011

Vincent H, Amri A, Castañeda-álvarez NP et al (2019) Modeling of crop wild relative species identifies areas globally for in situ conservation. Commun Biol 2:1-8. https://doi.org/10.1038/ s42003-019-0372-z

Wadley RL, Colfer CJP (2004) Sacred forest, hunting, and conservation in West Kalimantan, Indonesia. Hum Ecol 32:313-338. https://doi.org/10.1023/B:HUEC.0000028084.30742.d0

Zhang H, Mittal N, Leamy LJ et al (2017) Back into the wild-apply untapped genetic diversity of wild relatives for crop improvement. Evol Appl 10:5-24. https://doi.org/10.1111/eva.12434

Publisher's Note Springer Nature remains neutral with regard to jurisdictional claims in published maps and institutional affiliations.

\section{Authors and Affiliations}

\section{Wiguna Rahman ${ }^{1,2}$ (D) Joana Magos Brehm ${ }^{1} \cdot$ Nigel Maxted $^{1} \cdot$ Jade Phillips $^{1}$. Aremi R. Contreras-Toledo ${ }^{3} \cdot$ Mariam Faraji $^{1} \cdot$ Mauricio Parra Quijano $^{4}$}

1 School of Biosciences, University of Birmingham, Edgbaston, Birmingham B15 2 TT, UK

2 Cibodas Botanic Garden, Indonesian Institute of Sciences, Cianjur, West Java, Indonesia

3 National Genetic Resources Center, National Forestry, Crops and Livestock Research Institute, Jalisco, 47600 Tepatitlán de Morelos, Mexico

4 Facultad de Ciencias Agrarias, Universidad Nacional de Colombia, Bogotá, Colombia 